Synthesis, part of a Special Feature on The Conservation and Restoration of Old Growth in Frequent-fire Forests of the American West

\title{
Past, Present, and Future Old Growth in Frequent-fire Conifer Forests of the Western United States
}

\author{
$\underline{\text { Scott R. Abella }}^{1}, \underline{W}$. Wallace Covington $^{2,3}, \underline{\text { Peter Z. Fulé }}^{2,3}, \underline{\text { Leigh B. Lentile }}^{4}$, \\ Andrew J. Sánchez. Meador $^{5}$, and Penelope Morgan ${ }^{4}$
}

\begin{abstract}
Old growth in the frequent-fire conifer forests of the western United States, such as those containing ponderosa pine (Pinus ponderosa), Jeffrey pine (P. jeffreyi), giant sequoia (Sequioa giganteum) and other species, has undergone major changes since Euro-American settlement. Understanding past changes and anticipating future changes under different potential management scenarios are fundamental to developing ecologically based fuel reduction or ecological restoration treatments. Some of the many changes that have occurred in these forests include shifts from historically frequent surface fire to no fire or to stand-replacing fire regimes, increases in tree density, increased abundance of fire-intolerant trees, decreases in understory productivity, hydrological alterations, and accelerated mortality of old trees. Although these changes are widespread, the magnitude and causes of changes may vary within and among landscapes. Agents of change, such as fire exclusion or livestock grazing, likely interacted and had multiple effects. For example, historical ranching operations may have altered both fire regimes and understory vegetation, and facilitated institutional fire exclusion through fragmentation and settlement. Evidence exists for large variation in presettlement characteristics and current condition of old growth across this broad forest region, although there are many examples of striking similarities on widely distant landscapes. Exotic species, climate change, unnatural stand-replacing wildfires, and other factors will likely continue to degrade or eradicate old growth in many areas. As a policy of fire exclusion is proving to be unsustainable, mechanical tree thinning, prescribed fire, or wildland fire use will likely be key options for forestalling continued eradication of old growth by severe crown fires. For many practical and societal reasons, the wildland-urban interface may afford some of the most immediate opportunities for re-establishing old growth typical of presettlement forests resistant to crown fires.
\end{abstract}

Key Words: ecological restoration; evolutionary environment; mixed conifer; management; Pinus jeffreyi; Pinus ponderosa; range of variability; Sequoia giganteum

\section{INTRODUCTION}

Ecological and human values of old-growth forests frequently differ from those of younger forests. For instance, old forests provide optimal habitat for some wildlife species, harbor unique genetic diversity, and have provided large-diameter wood products to society (Kaufmann et al. 1992, Johnson 1994, Barbour et al. 2002). Old forests also provide other ecosystem services that may become increasingly important to society, such as carbon sequestration and watershed hydrology (Tecle and Covington 1991). The values of old forests result from many long-lived ecosystem components, including, but not limited to, trees. Sagebrush (Artemisia tridentata), for example, a major shrub species of many frequent-fire forests in the western
United States, can live for more than 70 years (Roughton 1972). There also can be old-growth ant colonies, as another example. Harvester ant (Pogonomyrmex owyheei) colonies can live for 30 years, with the mounds potentially reactivated by future colonies so that an individual ant mound can persist for centuries (Porter and Jorgensen 1988).

Old-growth forests have become rare across the United States, including in frequent-fire conifer forests of the West. These forests are one of the most extensive forest types in the western United States, covering tens of millions of hectares from Texas west and north to eastern Washington (Brown 1994, Everett et al. 1994, Kaufmann et al. 2004). Concerns by the public, resource managers, and scientists about deleterious conditions in both old and young 
frequent-fire forests have led to calls for regionwide fuel reduction and ecological restoration treatments (Covington et al. 1994, Dahms and Geils 1997, Keeley and Stephenson 2000). Ecologically based forest management requires understanding disturbance regimes and ranges of variability in oldgrowth forests before onset of deleterious conditions, the suite of changes that have taken place, and the mechanisms underlying the changes (Cooper 1960, Vankat and Major 1978, GrissinoMayer et al. 2004).

Our objectives are to provide an overview of changes that have occurred since Euro-American settlement in coniferous, old-growth, frequent-fire forests in the western United States, and to hypothesize anticipated changes in old growth that may result from potential management and policy scenarios. An exhaustive literature review is beyond the scope of this manuscript. Rather, we synthesize general principles, supported with examples from research conducted throughout the region. We begin by briefly summarizing the ecology of western frequent-fire conifer forests, the evolutionary environment concept as related to changes in old growth, and a broad old-growth classification defined for this manuscript.

\section{Western Frequent-fire Conifer Forests}

There is a continuum of fire frequencies in western forests (Swetnam and Baisan 1996, Caprio and Lineback 2002, Agee 2003), and in this review, we consider forests with average fire-return intervals of generally less than 20 years to be frequent-fire forests. Overstories of frequent-fire conifer forests often consist of pure or mixed ponderosa pine (Pinus ponderosa), Jeffrey pine (Pinus jeffreyi), giant sequoia (Sequoia giganteum), and various other species, such as western larch (Larix occidentalis) or Douglas-fir (Pseudotsuga menziesii) (Biswell 1972, Habeck 1990, Brown 1994). These forests occupy parts of western Texas, New Mexico, Arizona, Utah, Nevada, California, Oregon, Washington, Montana, Idaho, and Wyoming (Little 1971). Many of these forests historically had firereturn intervals far less than 20 years, such as 9 years in Jeffrey pine forests in the eastern Sierra Nevada Mountains (Stephens 2001), 7 years in ponderosa pine-western larch forests in western Montana (Habeck 1990), and 10 years on average for several studies in giant sequoia forests in California (Caprio and Lineback 2002; Table 1). Some forests containing these species, e.g., some areas of ponderosa pine in the Colorado Front Range or in the South Dakota Black Hills, also may have exhibited lengthier fire return intervals (Shinneman and Baker 1997, Brown et al. 2000). Forests characterized by stand-replacing fire regimes are not covered in this review. Many fires before EuroAmerican settlement in western frequent-fire forests are thought to have resulted from lightning ignitions (Swetnam and Baisan 1996), although there may have been some areas where Native American ignitions augmented fire frequencies (Agee 2003). Euro-American settlement varied in time and pattern within this forest region, although it generally occurred from the mid-1800s to the early 1900s (Stephenson 1999, Ehle and Baker 2003, Taylor and Beaty 2005). Uneven-agedness is an often-cited characteristic of overstory trees of presettlement or contemporary old-growth frequentfire forests, apparently resulting from an individualtree replacement or patch-scale regeneration pattern (White 1985). Sub-canopy tree composition varies, ranging from an absence of sub-canopy trees in some forests, to well-developed sub-canopies including Gambel oak (Quercus gambelii), mountain mahogany (Cercocarpus montanus), junipers (Juniperus spp.), and other species. Understories also vary widely, ranging from grassy understories (Kerns et al. 2003) to shrub-dominated or sparsely vegetated understories (Evett et al. 2006).

\section{The Evolutionary Environment Concept}

The concept of an evolutionary environment is central to understanding past forest changes and management needs for old-growth, frequent-fire forests. An evolutionary environment refers to the range of natural variability in ecological conditions in which a species or groups of species evolved (Morgan et al. 1994, Covington et al. 1999, Moore et al. 1999). In the context of contemporary ecosystems, the relevant evolutionary environment is often judged to be the past several thousand years, sometimes estimated as 50-100 times the average life span of the longest-lived ecological dominants. Based on this relationship, MacArthur (1972) concluded that "...the length of time it normally takes for a species to split and diverge sufficiently to be regarded as two species is a small, uncertain number of thousands of years." In North America, the recent evolutionary environment is often 
Table 1. Examples of pre-Euro-American settlement fire frequencies in frequent-fire conifer forests of the western United States

\begin{tabular}{|c|c|c|c|c|}
\hline Location & Major species $\dagger$ & MFI (yrs.) $\ddagger$ & Period & Reference \\
\hline Guadalupe Mountains, TX & pipo, mc & 5 & 1700-1900 & Swetnam and Baisan 1996 \\
\hline San Juan National Forest, CO & pipo, quga & $7-13$ & $1679-1880$ & Grissino-Mayer et al. 2004 \\
\hline El Malpais National Monument, NM & pipo & $5-17$ & $1700-1900$ & Swetnam and Baisan 1996 \\
\hline Rincon Mountains, AZ & pipo, quga & $6-10$ & $1657-1893$ & Baisan and Swetnam 1990 \\
\hline Camp Navajo, AZ & pipo, quga & 4 & $1637-1883$ & Fulé et al. 1997 \\
\hline Zion National Park, UT & pipo, quga & $4-7$ & pre-1881 & Madany and West 1983 \\
\hline Carson Range, NV & pije, abco & 2 & $1650-1850$ & Taylor and Beaty 2005 \\
\hline $\begin{array}{l}\text { Sequoia/Kings Canyon National Park, } \\
\text { CA§ }\end{array}$ & pipo, mc & 4 & pre-1860 & Caprio and Lineback 2002 \\
\hline Sequoia/Kings Canyon National Park, CA & $\mathrm{abco}, \mathrm{mc}$ & 10 & pre-1860 & Caprio and Lineback 2002 \\
\hline Sequoia/Kings Canyon National Park, CA & segi & 10 & pre-1860 & Caprio and Lineback 2002 \\
\hline Cascade Range, CA & abco, pije & 4 & $1652-1918$ & Bekker and Taylor 2001 \\
\hline Cascade Range, CA & abco, pila & 9 & $1658-1904$ & Bekker and Taylor 2001 \\
\hline Cascade Range, CA & abma, abco & 10 & 1694-1899 & Bekker and Taylor 2001 \\
\hline Eastern Sierra Nevada Mountains, CA & pije, abma & 9 & $1745-1889$ & Stephens 2001 \\
\hline Clearwater River drainage, ID & psme & 15 & - & Smith and Fischer 1997 \\
\hline Pattee Canyon, MT & pipo, laoc & 7 & $1557-1918$ & Habeck 1990 \\
\hline Eastern WA§ & psme & $6-18$ & - & Agee 2003 \\
\hline Cascade Range, WA & pipo, psme & 7 & $1700-1860$ & Everett et al. 2000 \\
\hline
\end{tabular}

$\dagger$ pipo $=$ Pinus ponderosa, $\mathrm{mc}=$ mixed conifer, quga $=$ Quercus gambelii, pije $=$ Pinus jeffreyi, abco $=$ Abies concolor, segi $=$ Sequoia giganteum, pila $=$ Pinus lambertiana, abma $=$ Abies magnifica, laoc $=$ Larix occidentalis, psme = Pseudotsuga menziesii.

$\$$ Mean fire return interval for all fire-scar samples.

$\S$ These studies represent syntheses of previous work in these regions. 
considered to include Native Americans as participants in evolutionary processes during the past 10000 years (Parsons et al. 1986). Over evolutionary time, species not only adapt to their evolutionary environment, but they may also come to depend on those conditions for their continued survival (Wilson 1992). Thus, the greatest threat to biological diversity is the loss of evolutionary habitats, and the greatest hope for reversing the losses is restoration of these habitats. Frequent surface fire was a dominant component of the evolutionary environment of the coniferous forests covered in this review. The rapidity and extent of fire exclusion and other alterations associated with Euro-American settlement are considered unprecedented in the recent evolutionary environment of frequentfire forests, and responsible for disrupting evolutionary trajectories and leading to pervasive ecosystem degradation (Biswell 1972, Allen et al. 2002).

\section{Old-growth Classification}

For the purpose of this review, we broadly classified old-growth forests into five types (Table 2). Most forest area existing before Euro-American settlement probably could be considered old growth, perhaps excepting locally cleared areas. We broadly differentiate two types of present old growth: unharvested forests dominated by old trees, and developing old growth consisting of older trees that are to be managed to attain old-growth characteristics (e.g., Morgan et al. 2002). Two types of future old growth represent the perpetuation of current or developing old growth.

\section{CHANGES AND AGENTS OF CHANGE}

Many agents, such as livestock grazing, fire exclusion and predator control (e.g., wolf eradication), began changing frequent-fire, oldgrowth forests in earnest following Euro-American settlement (Table 3). Some agents, such as fire exclusion partly resulting from a federal policy of suppressing fire starts in the western states, were widespread. Other agents may have varied in importance within and among landscapes, as they do today. For example, hydrological or vegetation modification by livestock ranching may have been most intense near watering areas within landscapes (Milchunas 2006). Many of the agents in Table 3 interacted with other agents and had multiple effects. For instance, both a policy of fire suppression and livestock grazing that may have decreased fine fuels in some areas could have contributed to fire exclusion (Madany and West 1983). In addition to potentially affecting fire regimes, multiple effects of this historical grazing also may have included reducing the abundance of palatable plant species and increasing soil erosion in some areas (Belsky and Blumenthal 1997). The following sections highlight some key historical changes occurring in frequent-fire old forests since settlement.

\section{Fire Regimes}

As frequent surface fire is thought to have shaped the evolutionary environment of frequent-fire conifer forests, the cessation of frequent fire through human activities has been cited as the most drastic change in these forests (Vankat and Major 1978, Keeling et al. 2006). In the past 100 years, many forests have "missed" more than 20 fires that would have occurred had evolutionary trajectories been allowed to continue (Table 1). It is not surprising that this alteration has been implicated in many changes in old-growth forests, including fuel buildups, tree density increases, shifts to fireintolerant trees, and alterations to understory plant composition (Kilgore 1971, Bonnicksen and Stone 1982). In particular, presettlement fires are thought to have partly regulated tree regeneration, possibly restricting regeneration to small fire-free "safe sites" (White 1985). Although fire exclusion has been a dominant occurrence since Euro-American settlement, it should not be overlooked that a period of severe fires associated with logging operations or other human activities may have briefly occurred following settlement in some areas before the initiation of fire exclusion (Smith and Fischer 1997).

In current old-growth forests managed with prescribed fire, the fires are often not synchronous with the timing of presettlement fires. For example, Fulé et al. (1997) found that $40 \%$ of presettlement fires occurred in spring (late April to June) and 60\% occurred in summer (July to early September) in northern Arizona ponderosa pine forests. Contemporary prescribed burns often occur in late fall or spring when fire is considered easier to control. Fall fires may reduce the abundance of warm-season grasses in forests where they are major 
Table 2. A broad classification of types of old-growth, frequent-fire forests considered in this article

\begin{tabular}{|c|c|c|}
\hline Time period & Type & Description \\
\hline Past & 1. Presettlement forests & Considered to have ended with the year of the last surface fire \\
\hline Present & 2. Old growth & $\begin{array}{l}\text { Unharvested, dominated by old trees, but typically affected by fire exclusion and } \\
\text { livestock }\end{array}$ \\
\hline Present & $\begin{array}{l}\text { 3. Developing old } \\
\text { growth }\end{array}$ & Forests managed to attain some or many old-growth characteristics in the future \\
\hline Future & 4. Old growth & Type 2 still dominated by old trees that may have been managed to varying degrees \\
\hline Future & 5. Emergent old growth & Type 3 that has attained some or many old-growth characteristics \\
\hline
\end{tabular}

components, but season of burn may have less of an effect in other forest types and vary with understory composition (Metlen and Fiedler 2006).

\section{Tree Composition}

Tree species dominant in presettlement forests had abilities for coping with frequent fire, such as thick bark or the production of plentiful seeds because many seedlings would be consumed by fire (Weaver 1947). Although not all areas of this forest region have exhibited increases in fire-intolerant species since Euro-American settlement, fire-intolerant species have proliferated in many areas (Zier and Baker 2006). Increases in these species can expand ladder fuels, modify soil characteristics due to differences in litter chemistry, and alter understory composition because of changes in solar radiation, canopy interception of precipitation, soil chemistry, or other factors (Moir 1966).

\section{Tree Structure and Pattern}

Probably the most striking and consistent change in old-growth forests since Euro-American settlement is burgeoning tree density, whether these increases result from dramatic population increases of original fire-adapted dominants, such as Jeffrey pine, invasion by fire-intolerant species, or both (Table 4). For example, more than 50 times more ponderosa pine trees currently occur in old-growth forests of the Gus Pearson Natural Area in northern
Arizona than occurred in 1876 at the time of settlement (Mast et al. 1999). Although the magnitude of tree-density increases varies within and among landscapes, most studies have found that densities have at least tripled since settlement (Table 4). In addition to increases in canopy trees, subcanopy trees such as Gambel oak also have irrupted in some areas (Fulé et al. 1997).

The proportion of trees in the largest diameter size classes have sharply decreased since EuroAmerican settlement, with the largest proportion of trees occupying small-diameter classes in current forests (Boyden et al. 2005). Old, large trees have been selectively harvested. The mortality of old trees has probably increased above that of natural attrition in many areas because of high densities of competing young trees, escalating insect or disease outbreaks, or increased stress due to climate change (Woodall et al. 2003, Breshears et al. 2005).

Although there are some exceptions, such as a random distribution found in an Oregon ponderosa pine stand (Youngblood et al. 2004), presettlement and current live old-growth trees often exhibit a clumped distribution within sites (Harrod et al. 1999). Thus, openings alternating with tree clumps typify within-forest patterns in many frequent-fire conifer forests. Tree density increases have resulted in the nearly complete or complete eradication of openings (Bonnicksen and Stone 1982, Zier and Baker 2006). These openings are important for understory vegetation, wildlife habitat, and aesthetic value (Tecle and Covington 1991). 
Table 3. Examples of agents of change and their effects in frequent-fire, old-growth conifer forests of the western United States

\begin{tabular}{lll}
\hline \hline Agent & $\begin{array}{l}\text { Examples of } \\
\text { potential effects }\end{array}$ & Reference \\
\hline
\end{tabular}

Fire-regime disruption

Fire exclusion

Increase fire severity

Ranching

Livestock grazing

Fragmentation

Watershed disruption

Wood harvesting

Large-tree removal

Road building

Fuelwood harvest

Other

Predator control

Exotic plants

Urban development

Climate change
Increase tree density

Eradicate old trees

Reduce palatable plants

Restrict wildlife movements

Damage/eradicate springs

Reduce some wildlife habitat

Spread exotic plants

Affect oak structure

Regional species extinctions

Reduce some native plants

Fragmentation

Increase tree mortality
Stephenson 1999

Savage and Mast 2005

Clary 1975

Milchunas 2006

Belsky and Blumenthal 1997

Tecle and Covington 1991

Fornwalt et al. 2003

Fulé et al. 1997

Dahms and Geils 1997

Keeley 2006

Dale 2006

Breshears et al. 2005

\section{Understory Vegetation}

Three of the primary agents of change in understory composition and productivity have been greater tree density, livestock grazing, and fire exclusion (Vankat and Major 1978). Understory productivity has declined in many areas, resulting from a welldocumented negative relationship between tree density and understory biomass (Clary 1975). A shift to increasing proportions of ecosystem biomass in woody plants relative to herbaceous plants is a common response to fire exclusion in many frequent-fire ecosystems, such as southern Texas grasslands (Archer 1990).
Livestock grazing has been cited as the most ubiquitous land use in the West, with the consequence that virtually no examples exist of oldgrowth forests with ungrazed understories (Milchunas 2006). Livestock density, including cattle, sheep, and horses, burgeoned in western forests through the 1800s. Disturbance caused by ranching operations preceded institutional fire suppression in many areas, and was often the earliest Euro-American disruption to old-growth forests (Belsky and Blumenthal 1997). Early ranching also facilitated subsequent settlement and its associated impacts (e.g., road building) to old-growth forests. Although native herbivores do occur in western 
Table 4. Examples of historical tree densities in frequent-fire forests, and the magnitude that tree densities have increased in contemporary forests above historical densities. Only studies that included dead wood in tree-density reconstructions are included, except for Habeck (1990), who corroborated results using historical land-survey records.

\begin{tabular}{|c|c|c|c|c|}
\hline Location & Major species $\dagger$ & Trees/ha & $x$ increase & Reference \\
\hline Cascade Mountains, WA & pipo, psme & $27-68$ & $3 \S$ & Harrod et al. 1999 \\
\hline Pattee Canyon, MT & pipo, laoc & $93-172$ & $3-8$ & Habeck 1990 \\
\hline Mt. Trumbull, AZ & pipo, quga, juos & 62 & 22 & Waltz et al. 2003 \\
\hline Grand Canyon, AZ & pipo, quga & $140-246$ & $3-7$ & Fulé et al. 2002 \\
\hline North Kaibab Plateau, AZ & pipo, quga & 138 & 5 & Covington and Moore 1994 \\
\hline San Francisco Peaks, AZ & pipo, mc & 52 & 25 & Heinlein et al. 2005 \\
\hline Near Flagstaff, AZ & pipo, quga & 148 & 9 & Fulé et al. 1997 \\
\hline Near Flagstaff, AZ & pipo & 60 & 52 & Mast et al. 1999 \\
\hline
\end{tabular}

$\dagger$ Major species recorded in historical forests: pipo $=$ Pinus ponderosa, psme $=$ Pseudotsuga menziesii, laoc = Larix occidentalis, quga $=$ Quercus gambelii, juos $=$ Juniperus osteosperma, $\mathrm{mc}=$ mixed conifer. $\ddagger$ Total tree density for all species. All studies, except Harrod et al. (1999) who reconstructed tree density in the year 1935, reconstructed tree density to years in the late 1800s, usually the time of the last recorded surface fire.

$\S$ Information on tree-density increases in this study was provided for one plant association that had a historical tree density of 45/ha.

frequent-fire forests, the geographic distribution and the high intensity of herbivory associated with livestock appear unprecedented.

When livestock exceed the carrying capacity of the land, they can affect understory plant communities directly by trampling or preferentially eating palatable species, either killing the plants or removing biomass or reproductive structures (Belsky and Blumenthal 1997). Heavy grazing can indirectly impact plants by affecting soils, native wildlife, and tree regeneration. By reducing competition from grasses and wildflowers, overgrazing may have contributed to tree-density increases and fire-regime disruption in western forests (Belsky and Blumenthal 1997). It is generally acknowledged that overgrazing occurred in many areas near the turn of the last century and that it exceeded the sustainable carrying capacity of the land (Covington et al. 1994). Grazing continues in many contemporary old-growth forests, although often the grazing is less heavy than historically. Nevertheless, vegetation state-and-transition modeling and other research suggest that compositional shifts resulting from early livestock grazing persist to the present in some areas, forming new, stable vegetation types often of inferior grazing quality than the original vegetation (Briske et al. 2005).

Changes in understory communities probably vary substantially both within and among landscapes, depending on both historical and contemporary disturbances, environmental site factors, and local species pools. For example, using phytolith (plant 
fossil) analysis in a California giant sequoia stand, Evett et al. (2006) found that grasses were sparse in presettlement understories as they are today. Conversely, following a phytolith analysis, Kerns et al. (2001) suggested that the abundance of grasses has decreased since Euro-American settlement in an old-growth Arizona ponderosa pine forest.

\section{Soils and Hydrology}

Since forest patterns often consist of tree clumps interspersed with canopy openings, different soils may develop below the different vegetation if the patch locations are stable for long time periods (i. e., for several generations of trees). Kerns et al. (2003) provided evidence that soils in grassy openings had thicker A horizons and higher $\mathrm{pH}$ than soils below old-growth clumps of ponderosa pine. This pattern of long-term soil development could have important ecological implications. For example, in an eastern Washington study, Moir (1966) found that grass biomass was $72 \%$ greater in soils collected below openings than below ponderosa pine. These findings suggest that converting tree patches to grassy patches and vice versa could result in soil homogenization, and may decrease grass productivity.

Other changes in soil properties in old-growth forests may have resulted from fire exclusion, treedensity increases, livestock grazing, changes in understory composition, or other factors. These changes may be as wide ranging as increases in soil bulk density in trampled areas of high livestock concentrations to accumulation of allelopathic chemicals from conifer litter because of increasing $\mathrm{O}$ horizons (litter and duff) during fire exclusion (Gundale and DeLuca 2006). Contemporary experiments provide some suggestions of potential changes in soil nutrient concentrations. For example, DeLuca and Sala (2006) found that forests at Montana and Idaho study sites burning as few as three times in the past 100 years had decreased total soil nitrogen, but greater available nitrogen than less frequently burned forests.

Because of their importance for human activities, the hydrology of springs and riparian areas often represents one of the characteristics most heavily modified by Euro-American settlement. Ranching operations resulted in pervasive diversion, damming, or piping of springs and drainages, with these alterations often causing long-term degradation of water supplies (Dahms and Geils 1997). In addition to greater human use of limited water supplies, post-settlement tree-density increases may also have altered water balances in some areas. For example, in a 4-year study, Brown et al. (1974) reported that streamflow increased on average $22 \%$ per year after tree thinning removed $75 \%$ of ponderosa pine basal area on the Beaver Creek watershed in Arizona. A grazing treatment (60\% utilization of perennial grasses) increased streamflow only $8 \%$, suggesting that the relative amounts of tree and understory biomass, which has been altered since Euro-American settlement, may affect water yield.

\section{Wildlife}

Predator control, hunting or trapping, livestock operations, fragmentation, and changing forest structure together with other factors have probably all affected wildlife. Some wildlife species, such as beaver (Castor canadensis) or gray wolves (Canis lupus), were driven to extinction regionally in the 1900s (Dahms and Geils 1997). Other species that benefit from dense forests have likely increased. Some game species also have increased, sometimes due to creation of supplemental water sources by game managers.

\section{Compounding Effects and Thresholds}

One view of ecosystems holds that ecosystems will adjust catastrophically to perturbations that exceed thresholds (Suding et al. 2004). Stand-replacing crown fire represents a catastrophic adjustment to change in old-growth forests formerly regulated by frequent surface fire (Scheffer et al. 2001). This adjustment can be viewed as catastrophic because it removes for centuries the long-lived ecologically dominant coniferous trees in frequent-fire forests. Savage and Mast (2005), for example, described a potential successional sequence where ponderosa pine forests were replaced by shrubfields forming a new, persistent vegetation type. Although these shrubfields also have ecological benefits, reestablishment of old-growth conifer forests on these sites could take centuries or millennia given episodic regeneration events in addition to changed site and climatic conditions (Lentile et al. 2005). 


\section{ANTICIPATED CHANGES}

\section{Fire}

Given current trends of increasing wildfire size and severity, coupled with climatic projections for enhancement of weather conditions promoting fire (Schoennagel et al. 2004), it seems probable that stand-replacing wildfire will continue to jeopardize or destroy existing old growth. These fires may have far-reaching effects on unburned old growth, such as potentially serving as focal points for exotic species infestations (Keeley 2006). Some of the most severe and extensive fires in recorded history have occurred in the last decade, illustrating that a policy of fire suppression cannot be successful indefinitely. McKenzie et al. (2004) compared temperature and precipitation of recorded wildfires in 11 western states, and then projected the effects of predicted climate change. Even in the best-case scenario with the smallest temperature increase, only $1.6^{\circ} \mathrm{C}$, the area burned was forecast to double by 2100 . Extrapolation of fire and climatic trends is an imprecise science, but considering that roughly $8 \%$ of the ponderosa pine forest in Arizona was burned in the 2002 Rodeo-Chediski Fire, it seems unlikely that it will take until 2100 to severely burn the majority of western frequent-fire forests, including most remaining old growth.

\section{Tree Composition and Structure}

Fire exclusion and climate change may represent conflicting factors affecting changes in tree species composition. Fire-intolerant species, which often exhibit a more mesic affinity, have increased in some areas during fire exclusion (Barbour et al. 2002). These species may continue to increase under continued fire exclusion. Conversely, climate change may result in an expansion of dry, firetolerant species, such as ponderosa pine (Heinlein et al. 2005). Thus, in the absence of fire, changes in tree composition may vary with elevation and with other environmental factors that affect moisture availability and growing conditions for trees.

\section{Understory Vegetation}

Understory vegetation in old-growth forests will likely continue to be affected by livestock grazing, elevated tree densities, lack of surface fire, and exotic plants. Livestock grazing decreased through the 1900s in some areas, but grazing intensity will likely continue to vary within and among landscapes. Based on state-and-transition models, Briske et al. (2005) suggest that the recovery of understory composition to that resembling a presettlement forest may be slow or non-existent with or without further livestock grazing. Changes in plant composition with changing levels of grazing pressure will likely vary with precipitation, soil types, future disturbances, and the species available in regional species pools (Abella and Covington 2006). Similar considerations also apply to potential changes in plant composition resulting from continued elevated tree densities. Openings may serve as refuges for understory plants, but these openings may further shrink with tree canopy encroachment. Protracted lack of fire may further reduce regeneration microsites, as accumulating litter layers become too thick to support plant establishment even given sufficient propagules (Laughlin et al. 2004). Exotic plants are particularly troubling because they may persist after wildfire or forest management activities designed to restore old growth (Fornwalt et al. 2003). Cheatgrass (Bromus tectorum) provides an example of potential effects of exotic plants, as this species establishes dense stands of continuous and highly flammable fuel that can hinder the restoration of a low-intensity surface fire regime (Keeley 2006).

\section{Wildlife}

It is difficult to generalize anticipated effects of forest conditions on wildlife except that continued dense forests may favor species benefiting from dense forests, whereas species requiring open forests may decline or persist at only small population sizes (Dahms and Geils 1997). Fragmentation of existing old growth, by wildfire or other factors, may continue to reduce the area of interior old growth suitable as habitat for some species (Tecle and Covington 1991). Developing old growth, as long as it is not burned by crown fire, may become increasingly important as habitat for some wildlife species because it may occupy a much larger area than current old growth. 


\section{POSSIBLE MANAGEMENT AND POLICY SCENARIOS}

\section{Fire Management}

Active fire suppression is likely to remain a central policy in the United States for several decades, both for social and practical reasons, and especially in the wildland-urban interface. A need to comply with rigorous planning requirements and regulations, a societal aversion to fire-created smoke, and dangerous fuel loads hinder the use of prescribed fire, particularly if mechanical tree thinning is not conducted first. Society may need to weigh the advantages and disadvantages of more frequent, but less concentrated, episodes of smoke associated with prescribed burning, compared with wildfire-induced, intense smoke that can affect regional air quality even $1000 \mathrm{~km}$ away from the wildfire. Regardless, the increasing size and severity of wildfires in recent years suggest that fire suppression is not a sustainable policy.

Prescribed burning is likely to remain a tool, but a financially costly one, for reducing fuel loads in oldgrowth forests. As prescribed fires burn when and where managers choose, within the "window" of appropriate weather conditions, managers can meet the goals of burning particular places at particular times. But prescribed fires require a substantial investment in people to ignite the burn and prepare and secure the control lines. Such financial costs are often acceptable for forests in the wildland-urban interface, where the social values at risk from unplanned wildfire are high. They may not be acceptable for large, remote forest lands, however. Wildland fire use (i.e., allowing unplanned ignitions to burn in certain areas for certain time periods) has potential, as yet largely unrealized, for restoring fire to old forests in remote areas at relatively low financial cost and also with less required environmental compliance (Dale 2006). Ecological benefits of these fires may hinge upon fire intensity remaining low, as the fires will likely be burning through forests with heavy fuel loads. Both simulation studies and field examples suggest that even when surface fires occur less frequently than they may have in presettlement forests, through time they are still valuable for maintaining open forest structure and reducing possibilities for severe wildfires (Miller and Urban 2000).

Reintroducing fire, whether through prescribed burning or wildland fire use, will be tricky in most old-growth or developing old-growth forests because these forests have not experienced fire in more than 100 years in most cases (Harrington and Sackett 1992). These forests are vastly different than their presettlement counterparts that sustained frequent surface fires. Examples of trade-offs when reintroducing fire may include killing some remaining old trees if fuel loads are too heavy (Swezy and Agee 1991) and expanding exotic plant populations resulting from disturbance caused by fire (Keeley 2006). However, if fuel reduction is not performed and a stand-replacing wildfire occurs, all old trees could be killed within a forest and exotic plant invasion will very likely take place. The effects of reintroducing fire may depend on fire severity, season of burning, how frequently fire is introduced through time, and environmental site conditions (Brown and Smith 2000, Smith 2000, Certini 2005).

\section{Mechanical Tree Thinning}

Converting forests from uneven-aged, patchy, oldgrowth trees to even-aged, evenly spaced, highdensity overstories almost certainly ended with the passage of the Healthy Forests Restoration Act in 2003 (P.L. 108-148). Tree-cutting practices in the West now, and probably in the future, will focus primarily on fuel reduction and restoration thinning, with occasional commercial harvests. Mechanical tree thinning of young, post-settlement trees often constitutes the first step in managing current old growth or facilitating the continued establishment of developing old growth. Thinning often is needed before surface fire can be safely reintroduced to old forests. Recent research has provided dramatic examples of the benefits of thinning for reducing fire severity and limiting or preventing crown fire (Strom and Fulé 2007). Thinning can also change stand structure favorably for understory vegetation and other ecosystem components.

Diameter caps, or the upper size limits of trees allowed to be cut, have the potential to produce enormous effects on existing old-growth or developing old-growth forests (Abella et al. 2006). Many forest thinning projects are currently being conducted with diameter caps. Diameter caps do not necessarily protect all old trees, because old trees can be smaller than the size of the cap. Conversely, caps can assure that all large (young or old) trees are not cut during thinning, which may assist the development of large-tree structure in developing old growth if the density of residual trees does not 
remain too high (Allen et al. 2002). High residual densities may slow tree growth and result in continued old tree mortality due to competition or insect outbreaks, and also may result in forests that can still support severe crown fire. Caps can benefit some ecosystem components, e.g., some wildlife that benefit from higher tree densities, but may harm other components such as understory vegetation and many other wildlife species. The crux of diameter caps is that they set minimum remaining tree densities after thinning, whether or not those densities meet the forest management goals of the thinning (Abella et al. 2006). There also may be reason to harvest some large (though not necessarily old) trees to partly offset costs of expensive fuelreduction projects, and potentially also funding other treatments (e.g., seeding for understory restoration) that may be critical for restoring components of old-growth forests other than just trees.

Thinning of dense post-settlement trees will likely remain a central management treatment for old forests, but will pose political, logistical, and ecological challenges in many areas. There is little market for small-diameter logs in most western forest regions (Fiedler et al. 1999), limiting contractor availability and making thinning expensive. Developing uses and markets for small logs may enhance the landscape-scale application of thinning, but this has been slow in many forest regions. Mechanized equipment generally needed to conduct thinning operations at ecologically meaningful scales also is prohibited in many wilderness areas and other protected areas that may contain old forests jeopardized by wildfire (Fulé et al. 2006). An additional disadvantage of thinning is that it causes disturbance by road construction and mechanized equipment, which may facilitate exotic species invasion (Fornwalt et al. 2003). Despite these disadvantages, there often is little choice but to conduct thinning if old growth is to be protected from eradication by severe fire and if key components of old-growth ecosystems (e.g., canopy openings) are to be restored.

\section{CONCLUSION}

The prognosis for protecting old growth from severe wildfire, insect outbreaks, and other damaging agents may appear grim in frequent-fire, conifer forests in the West. Given the extreme stresses that these forests have sustained, however, it could be argued that it is remarkable that any old-growth forests have persisted at all, and of these, that their conditions are as good as they are. Virtually no oldgrowth forests remain that resemble those of presettlement conditions, however, and if current trends of severe wildfires continue, little of even this modified old growth will remain in the coming decades. A realistic appraisal of fuel and climate suggests that many old, frequent-fire, conifer forests in the West will burn severely in the coming decades even as ambitious restoration or fuel-reduction efforts proceed. However, there is clear evidence that wildfire severity can be reduced significantly in even the worst fire weather by tree thinning or burning treatments. A practical $21^{\text {st }}$ century fire strategy might position treatments to break up landscape fuel continuity (Finney 2001), allow wildland fire use to reduce backcountry fuels where thinning is too costly or not feasible, and make use of longer fire intervals and multiple ignition sources.

Responses to this article can be read online at:

http://www.ecologyandsociety.org/vol12/iss2/art16/responses/

\section{LITERATURE CITED}

Abella, S. R., and W. W. Covington. 2006. Forest ecosystems of an Arizona Pinus ponderosa landscape: multifactor classification and implications for ecological restoration. Journal of Biogeography 33: $1368-1383$.

Abella, S. R., P. Z. Fulé, and W. W. Covington. 2006. Diameter caps for thinning southwestern ponderosa pine forests: viewpoints, effects, and tradeoffs. Journal of Forestry 104:407-414.

Agee, J. K. 2003. Historical range of variability in eastern Cascades forests, Washington, USA. Landscape Ecology 18:725-740.

Allen, C. D., M. Savage, D. A. Falk, K. F. Suckling, T. W. Swetnam, T. Shulke, P. B. Stacey, P. Morgan, M. Hoffman, and J. T. Klingel. 2002. Ecological restoration of southwestern ponderosa pine ecosystems: a broad perspective. Ecological Applications 12:1418-1433.

Archer, S. 1990. Development and stability of grass/woody mosaics in a subtropical savanna parkland, Texas, U.S.A. Journal of Biogeography 17:453-462. 
Baisan, C. H., and T. W. Swetnam. 1990. Fire history on a desert mountain range: Rincon Mountain Wilderness, Arizona, U.S.A. Canadian Journal of Forest Research 20:1559-1569.

Barbour, M., E. Kelley, P. Maloney, D. Rizzo, E. Royce, and J. Fites-Kaufmann. 2002. Present and past old-growth forests of the Lake Tahoe Basin, Sierra Nevada, US. Journal of Vegetation Science 13:461-472.

Bekker, M. F., and A. H. Taylor. 2001. Gradient analysis of fire regimes in montane forests of the southern Cascade Range, Thousand Lakes Wilderness, California, USA. Plant Ecology 155:15-28.

Belsky, A. J., and D. M. Blumenthal. 1997. Effects of livestock grazing on stand dynamics and soils in upland forests of the Interior West. Conservation Biology 11:315-327.

Biswell, H.H. 1972. Fire ecology in ponderosa-pine grassland. Tall Timbers Fire Ecology Conference Proceedings 12:69-97.

Bonnicksen, T. M., and E. C. Stone. 1982. Reconstruction of a presettlement giant sequoiamixed conifer forest community using the aggregation approach. Ecology 63:1134-1138.

Boyden, S., D. Binkley, and W. Shepperd. 2005. Spatial and temporal patterns in structure, regeneration, and mortality of an old-growth ponderosa pine forest in the Colorado Front Range. Forest Ecology and Management 219:43-55.

Breshears, D. D., N. S. Cobb, P. M. Rich, K. P. Price, C. D. Allen, R. G. Ballce, W. H. Romme, J. H. Kastens, M. L. Floyd, J. Belnap, J. J. Anderson, O. B. Myers, and C. D. Meyer. 2005. Regional vegetation die-off in response to globalchange-type drought. Proceedings of the National Academy of Sciences 102:15144-15148.

Briske, D. D., S. D. Fuhlendorf, and F. E. Smeins. 2005. State-and-transition models, thresholds, and rangeland health: a synthesis of ecological concepts and perspectives. Rangeland Ecology and Management 58:1-10.

Brown, D. E., editor. 1994. Biotic communities: southwestern United States and northwestern Mexico. University of Utah Press, Salt Lake City, Utah, USA.
Brown, H. E., M. B. Baker, J. J. Rogers, W. P. Clary, J. L. Kovner, F. R. Larson, C. C. Avery, and R. E. Campbell. 1974. Opportunities for increasing water yields and other multiple use values on ponderosa pine forest lands. U.S. Forest Service Research Paper RM-129.

Brown, J. K., and J. K. Smith, editors. 2000. Wildland fire in ecosystems: effects of fire on flora. U.S. Forest Service General Technical Report 42, volume 2 .

Brown, P. M., M. G. Ryan, and T. G. Andrews. 2000. Historical fire frequency in ponderosa pine stands in research natural areas, central Rocky Mountains and Black Hills, US. Natural Areas Journal 20:133-139.

Caprio, A. C., and P. Lineback. 2002. Pretwentieth century fire history of Sequoia and Kings Canyon National Park: a review and evaluation of our knowledge. Pages 180-199 in Proceedings of the conference on fire in California ecosystems: integrating ecology, prevention, and management. Miscellaneous Publication No. 1. Association for Fire Ecology, Davis, California, USA.

Certini, G. 2005. Effects of fire on properties of forest soils: a review. Oecologia 143:1-10.

Clary, W. P. 1975. Range management and its ecological basis in the ponderosa pine type of Arizona: the status of our knowledge. U.S. Forest Service Research Paper RM-158.

Cooper, C. F. 1960. Changes in vegetation, structure, and growth of southwestern pine forests since white settlement. Ecological Monographs 30:129-164.

Covington, W. W., W. A. Niering, E. Starkey, and J. Walker. 1999. Ecosystem restoration and management: scientific principles and concepts. Pages 599-617 in Ecological stewardship: a common reference for ecosystem management. Elsevier Scientific, Ltd., Oxford, UK.

Covington, W. W., and M. M. Moore. 1994. Postsettlement changes in natural fire regimes and forest structure: ecological restoration of oldgrowth ponderosa pine forests. Journal of Sustainable Forestry 2:153-181.

Covington, W. W., R. L. Everett, R. Steele, L. L. Irwin, T. A. Daer, and A. N. D. Auclair. 1994. 
Historical and anticipated changes in forest ecosystems of the inland west of the United States. Journal of Sustainable Forestry 2:13-63.

Dahms, C. W., and B. W. Geils, technical editors. 1997. An assessment of forest ecosystem health in the Southwest. U.S. Forest Service General Technical Report RM-GTR-295.

Dale, L. 2006. Wildfire policy and fire use on public lands in the United States. Society and Natural Resources 19:275-284.

DeLuca, T. H., and A. Sala. 2006. Frequent fire alters nitrogen transformations in ponderosa pine stands of the Inland Northwest. Ecology 87:25112522.

Ehle, D. S., and W. L. Baker. 2003. Disturbance and stand dynamics in ponderosa pine forests in Rocky Mountain National Park, USA. Ecological Monographs 73:543-566.

Everett, R., P. Hessburg, J. Lehmkuhl, M. Jensen, and P. Bourgeron. 1994. Old forests in dynamic landscapes: dry site forests in eastern Oregon and Washington. Journal of Forestry 92:2225.

Everett, R., R. Schellhaus, D. Keenum, D. Spurbeck, and P. Ohlson. 2000. Fire history in the ponderosa pine/Douglas-fir forests on the east slope of the Washington Cascades. Forest Ecology and Management 129:207-225.

Evett, R. R., R. A. Woodward, W. Harrison, J. Suero, P. Raggio, and J. W. Bartolome. 2006. Phytolith evidence for the lack of a grass understory in a Sequoiadendron giganteum (Taxodiaceae) stand in the central Sierra Nevada, California. Madroño 53:351-366.

Fiedler, C. E., C. E. Keegan, D. P. Wichman, and S. F. Arno. 1999. Product and economic implications of ecological restoration. Forest Products Journal 49:19-23.

Finney, M. A. 2001. Design of regular landscape fuel treatment patterns for modifying fire growth and behavior. Forest Science 47:219-228.

Fornwalt, P. J., M. R. Kaufmann, L. S. Huckaby, J. M. Stoker, and T. J. Stohlgren. 2003. Non-native plant invasions in managed and protected ponderosa
pine/Douglas-fir forests of the Colorado Front Range. Forest Ecology and Management 177:515527.

Fulé, P. Z., W. W. Covington, and M. M. Moore. 1997. Determining reference conditions for ecosystem management of southwestern ponderosa pine forests. Ecological Applications 7:895-908.

Fulé, P. Z., W. W. Covington, M. M. Moore, T. A. Heinlein, and A. E. M. Waltz. 2002. Natural variability in forests of the Grand Canyon, USA. Journal of Biogeography 29:31-47.

Fulé, P. Z., W. W. Covington, M. T. Stoddard, and D. Bertolette. 2006. "Minimal-impact" restoration treatments have limited effects on forest structure and fuels at Grand Canyon, USA. Restoration Ecology 14:357-368.

Grissino-Mayer, H. D., W. H. Romme, L. M. Floyd, and D.D. Hanna. 2004. Climatic and human influences on fire regimes of the southern San Juan Mountains, Colorado, USA. Ecology 85:17081724.

Gundale, M. J., and T. H. DeLuca. 2006. Temperature and source material influence ecological attributes of ponderosa pine and Douglas-fir charcoal. Forest Ecology and Management 231:86-93.

Habeck, J. R. 1990. Old-growth ponderosa pinewestern larch forests of western Montana: ecology and management. Northwest Environmental Journal 6:271-292.

Harrington, M. G., and S. S. Sackett. 1992. Past and present fire influences on southwestern ponderosa pine old growth. Pages 44-50 in M. R. Kaufmann, W. H. Moir, and R. L. Bassett, technical coordinators. Old-growth forests in the Southwest and Rocky Mountain regions: proceedings of a workshop. U.S. Forest Service General Technical Report RM-213.

Harrod, R. J., B. H. McRae, and W. E. Hartl. 1999. Historical stand reconstruction in ponderosa pine forests to guide silvicultural prescriptions. Forest Ecology and Management 114:433-446.

Heinlein, T. A., M. M. Moore, P. Z. Fulé, and W. W. Covington. 2005. Fire history and stand structure of two ponderosa pine-mixed conifer 
sites: San Francisco Peaks, Arizona, USA. International Journal of Wildland Fire 14:307-320.

Johnson, M. A. 1994. Changes in southwestern forests: Stewardship implications. Journal of Forestry 92:16-19.

Kaufmann, M. R., W. H. Moir, and W. W. Covington. 1992. Old-growth forests: what do we know about their ecology and management in the Southwest and Rocky Mountain regions? Pages 111 in M.R. Kaufmann, W.H. Moir, and R.L. Bassett, technical coordinators. Old-growth forests in the Southwest and Rocky Mountain regions: proceedings of a workshop, 1992, Portal, Arizona, USA. U.S. Forest Service General Technical Report RM-213.

Kaufmann, M. R., K. Ryan, P. Z. Fulé, and W. H. Romme. 2004. Restoration of ponderosa pine forests in the interior western United States after logging, grazing, and fire suppression. Pages 481500 in J. A. Stanturf and P. Madsen, editors. Restoration of boreal and temperate forests. CRC Press, Boca Raton, Florida, USA.

Keeley, J. E. 2006. Fire management impacts on invasive plants in the western United States. Conservation Biology 20:375-384.

Keeley, J. E., and N. L. Stephenson. 2000. Restoring natural fire regimes to the Sierra Nevada in an era of global change. Pages 255-265 in D. N. Cole, S. F. McCool, W. T. Borrie, and J. O'Laughlin, compilers. Wilderness science in a time of change conference-volume 5: wilderness ecosystems, threats, and management, 1999, Missoula, Montana, USA. U.S. Forest Service Proceedings RMRS-P-15-VOL-5.

Keeling, E. G., A. Sala, and T. H. DeLuca. 2006. Effects of fire exclusion on forest structure and composition in unlogged ponderosa pine/Douglasfir forests. Forest Ecology and Management 237:418-428.

Kerns, B. K., M. M. Moore, and S. C. Hart. 2001. Estimating forest-grassland dynamics using soil phytolith assemblages and ${ }^{13} \mathrm{C}$ of soil organic matter. Ecoscience 8:478-488.

Kerns, B. K., M. M. Moore, M. E. Timpson, and S. C. Hart. 2003. Soil properties associated with vegetation patches in a Pinus ponderosabunchgrass mosaic. Western North American
Naturalist 63:452-462.

Kilgore, B. M. 1971. Response of breeding bird populations to habitat changes in a giant sequoia forest. American Midland Naturalist 85:135-152.

Laughlin, D. C., J. D. Bakker, M. T. Stoddard, M. L. Daniels, J. D. Springer, C. N. Gildar, A. M. Green, and W. W. Covington. 2004. Toward reference conditions: wildfire effects on flora in an old-growth ponderosa pine forest. Forest Ecology and Management 199:137-152.

Lentile L. B., F. W. Smith, and W. D. Shepperd. 2005. Patch structure, fire-scar formation and tree regeneration in a large mixed-severity fire in the South Dakota Black Hills, USA. Canadian Journal of Forest Research 35:2875-2885.

Little, E. L. 1971. Atlas of United States trees. Volume 1. Conifers and important hardwoods. U.S. Department of Agriculture Miscellaneous Publication 1146. U.S. Government Printing Office, Washington, D.C., USA.

MacArthur, R. H. 1972. Geographical ecology: patterns in the distribution of species. Princeton University Press, Princeton, New Jersey, USA.

Madany, M. H., and N. E. West. 1983. Livestock grazing-fire regime interactions within montane forests of Zion National Park, Utah. Ecology 64:661-667.

Mast, J. N., P. Z. Fulé, M. M. Moore, W. W. Covington, and A. E. M. Waltz. 1999. Restoration of presettlement age structure of an Arizona ponderosa pine forest. Ecological Applications 9:228-239.

McKenzie, D., Z. Gedalof, D. L. Peterson, and P. Mote. 2004. Climate change, wildfire, and conservation. Conservation Biology 18:890-902.

Metlen, K. L., and C. E. Fiedler. 2006. Restoration treatment effects on the understory of ponderosa pine/Douglas-fir forests in western Montana, USA. Forest Ecology and Management 222:355-369.

Milchunas, D. G. 2006. Responses of plant communities to grazing in the southwestern United States. U.S. Forest Service General Technical Report RMRS-GTR-169. 
Miller, C., and D. L. Urban. 2000. Modeling the effects of fire management alternatives on Sierra Nevada mixed-conifer forests. Ecological Applications 10:85-94.

Moir, W. H. 1966. Influence of ponderosa pine on herbaceous vegetation. Ecology 47:1045-1048.

Moore, M. M., W. W. Covington, and P. Z. Fulé. 1999. Reference conditions and ecological restoration: a southwestern ponderosa pine perspective. Ecological Applications 9:1266-1277.

Morgan, P., G. H. Aplet, J. B. Haufler, H. C. Humphries, M. M. Moore, and W. D. Wilson. 1994. Historical range of variability: a useful tool for evaluating ecosystem change. Journal of Sustainable Forestry 2:87-111.

Morgan, T. A., C. E. Fiedler, and C. Woodall. 2002. Characteristics of dry site old-growth ponderosa pine in the Bull Mountains of Montana, USA. Natural Areas Journal 22:11-19.

Parsons, D. J., D. M. Graber, J. K. Agee, and J. W. van Wagtendonk. 1986. Natural fire management in national parks. Environmental Management 10:21-24.

Porter, S. D., and C. D. Jorgensen. 1988. Longevity of harvester ant colonies in southern Idaho. Journal of Range Management 41:104-107.

Roughton, R. D. 1972. Shrub age structures on a mule deer winter range in Colorado. Ecology 53:615625.

Savage, M., and J. N. Mast. 2005. How resilient are southwestern ponderosa pine forests after crown fires? Canadian Journal of Forest Research 35:967977.

Scheffer, M., S. Carpenter, J. Foley, C. Folke, and B. Walker. 2001. Catastrophic shifts in ecosystems. Nature 413:591-596.

Schoennagel T. L., T. T. Veblen, and W. H. Romme. 2004. The interaction of fire, fuels and climate across Rocky Mountain forests. BioScience 54:661-676.

Shinneman, D. J., and W. L. Baker. 1997. Nonequilibrium dynamics between catastrophic disturbances and old-growth forests in ponderosa pine landscapes of the Black Hills. Conservation Biology 11:1276-1288.

Smith, J.K., editor. 2000. Wildland fire in ecosystems: effects of fire on fauna. U.S. Forest Service General Technical Report RMRSGTR-42, volume 1.

Smith, J. K., and W. C. Fischer. 1997. Fire ecology offorest habitat types of northern Idaho. U.S. Forest Service General Technical Report INT-GTR-363.

Stephens, S. L. 2001. Fire history of adjacent Jeffrey pine and upper montane forests in the eastern Sierra Nevada. International Journal of Wildland Fire 10:161-176.

Stephenson, N. L. 1999. Reference conditions for giant sequoia forest restoration: structure, process, and precision. Ecological Applications 9:12531265 .

Strom, B. A., and P. Z. Fulé. 2007. Pre-wildfire fuel treatments affect long-term ponderosa pine forest dynamics. International Journal of Wildland Fire 16:128-138.

Suding, K. N., K. L. Gross, and G. R. Houseman. 2004. Alternative states and positive feedbacks in restoration ecology. Trends in Ecology and Evolution 19:46-53.

Swetnam, T. W., and C. H. Baisan. 1996. Historical fire regime patterns in the southwestern United States since AD 1700. Pages 11-32 in C. D. Allen, technical editor. Fire effects in southwestern forests: proceedings of the second La Mesa Fire symposium, 1994, Los Alamos, New Mexico, USA. U.S. Forest Service General Technical Report RMGTR-286.

Swezy, D. M., and J. K. Agee. 1991. Prescribedfire effects on fine-root and tree mortality in oldgrowth ponderosa pine. Canadian Journal of Forest Research 21:626-634.

Taylor, A. H., and R. M. Beaty. 2005. Climatic influences on fire regimes in the northern Sierra Nevada Mountains, Lake Tahoe Basin, Nevada, USA. Journal of Biogeography 32:425-438.

Tecle, A., and W. W. Covington, technical editors. 1991. Multiresource management of southwestern ponderosa pine forests: the status of knowledge. U. 
S. Forest Service, Southwestern Region, Albuquerque, New Mexico, USA.

Vankat, J. L., and J. Major. 1978. Vegetation changes in Sequoia National Park, California. Journal of Biogeography 5:377-402.

Waltz, A. E. M., P. Z. Fulé, W. W. Covington, and M. M. Moore. 2003. Diversity in ponderosa pine forest structure following ecological restoration treatments. Forest Science 49:885-900.

Weaver, H. 1947. Fire-nature's thinning agent in ponderosa pine stands. Journal of Forestry 45:437444.

White, A. S. 1985. Presettlement regeneration patterns in a southwestern ponderosa pine stand. Ecology 66:589-594.

Wilson, E. O. 1992. The diversity of life. W.W. Norton and Company, New York, New York, USA.

Woodall, C. W., C. E. Fiedler, and K. S. Milner. 2003. Inter-tree competition in uneven-aged ponderosa pine stands. Canadian Journal of Forest Research 33:1719-1726.

Youngblood, A., T. Max, and K. Coe. 2004. Stand structure in eastside old-growth ponderosa pine forests of Oregon and northern California. Forest Ecology and Management 199:191-217.

Zier, J. L., and W. L. Baker. 2006. A century of vegetation change in the San Juan Mountains, Colorado: an analysis using repeat photography. Forest Ecology and Management 228:251-262. 